\title{
9 Company-Relevant Stakeholders-Based Management System
}

\section{Company Management System Concept}

Organization management is the science and the art to combine resources and work processes to generate performance. The management is a vector of the economic and social development, with a decisive contribution in obtaining multidimensional performances. Organization management contains a set of the management processes and relationships, which involve all employees and work processes.

Management processes mean all the phases that determine the objectives of the company and the subsystems incorporated, the resources, the work processes, and the employees necessary to achieve them, using a set of systems, methods, and techniques to efficiently fulfil the organization's founding purpose. Management processes are characterised by the fact that a part of human resources - the managers - decide and act on the work of the other part - the organization's employees - to achieve the highest performance possible.

Within the management processes, we could separate several main components, the management functions: prevision, organization, coordination, motivation, and control evaluation. ${ }^{1}$ These functions represent the content of the standard management processes used in any type of organization, despite their specific features. Although the management processes usually represent only a small percentage of all company work processes, because of the specific content, complexity, and implications, they often have a decisive role in gaining competitiveness. In fact, the management processes and the execution processes are complementary, their separation being the normal result of the work labour division. Management processes determine the enhancement of the execution processes, productivity, and more rational harmonisation of work results, according to economic and social requirements, to the demands of the organization's clients.

Management relationships are the second element of the management and determine its specificity and results. Essentially, the management relationship could be defined as the connection among the company

DOI: $10.4324 / 9781003217701-9$ 
employees and between them and the components of other systems in the processes of prevision, organization, coordination, motivation, and control evaluation. Analysis of the factors that influence the management relationship characteristics in the company reveals a triple determination: social-economic, technical-material, and human. ${ }^{2}$

Numerous concepts, approaches, principles, systems, methods, techniques, procedures have been elaborated to modelate and exercise effectively and efficiently the management processes and relationships. Gradually, organizations' management become professionalised, substantially increasing their rationality and performance.

Company management systems' design and implementation represent a major contribution to management professionalisation. The first company professional-specific management systems were developed after the Second World War to solve the complex business, social, and political problems generated by the transition from the "war economy" to the "normal" economy in the challenging international context. In Figure 9.1, we indicate the most marketed and used company management systems.

A company management system could be defined as a coherent ensemble of elements - principles, rules, structures, methods and procedures - used for the modelation and utilisation in a specific manner of all or most of the management processes and relationships in the entire organization or in a large part of it to amplify the efficacy and efficiency and to achieve sustainable competitiveness (Nicolescu \& Verboncu, 2008). We outline that the company management systems are different from management techniques - like SWOT analysis, business plan, job enlargement, career plan, decisional tree, Gant diagram, and managerial simulation - especially regarding the size of the work processes involved and the complexity. Management system covers all or a major part of the entire organization's activities. Management technique usually deals with managerial tasks or a set of tasks, which should be done by one or a few company managers. Management systems have greater complexity, incorporating several managerial techniques to be used independently. Management technique is a basic entity, which could not be divided without breaking down or radically changing its structure, content, and finality.

Management system creation and use represent a superior phase in the development of the management theory and practice (see Figure 9.2) because:

a Management systems approach and remodel a set of management processes and relationships in the company, being a systemic managerial mechanism.

b Management systems focus on the achievement of the companyspecific objectives that are well defined and often quantified 


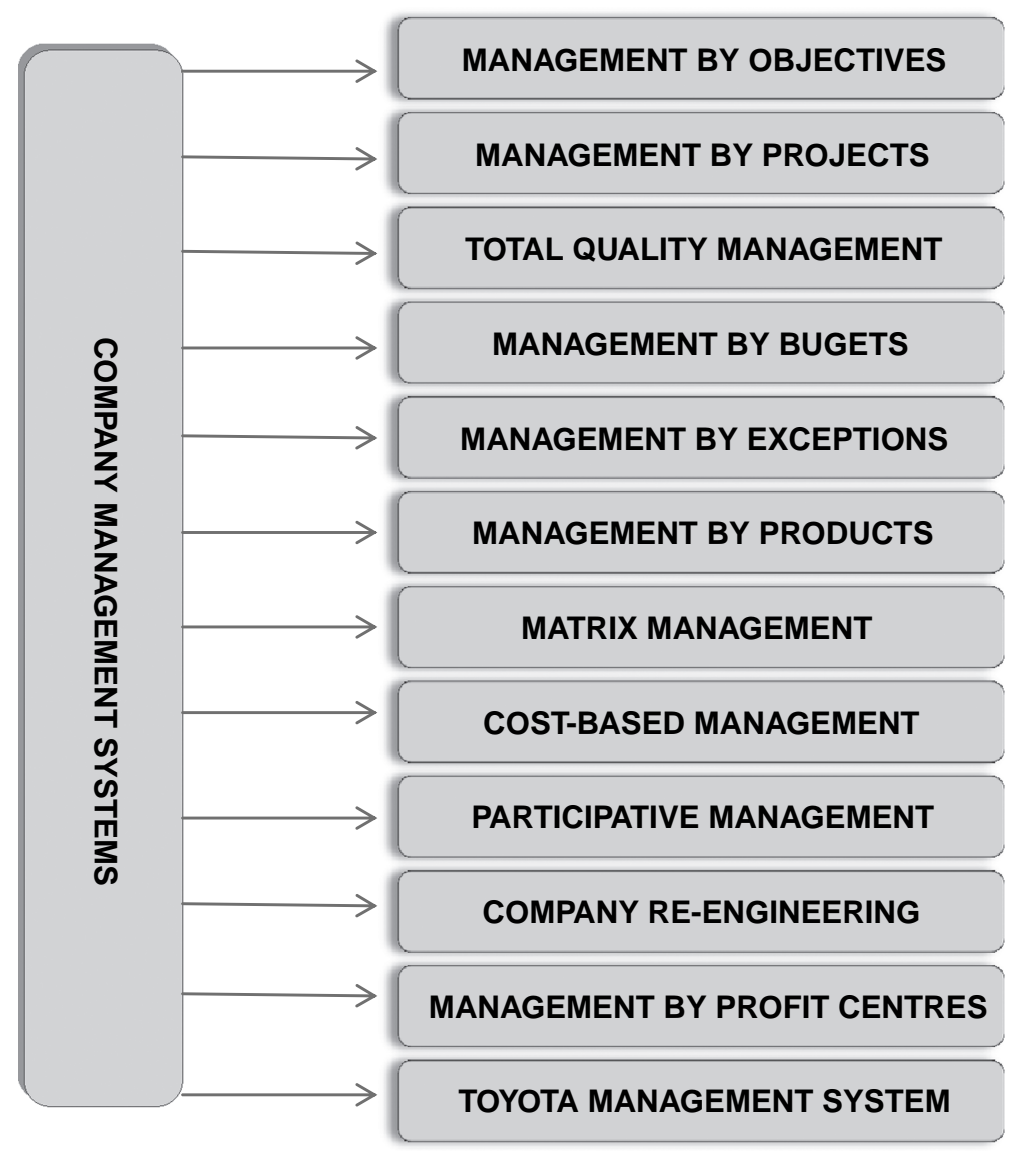

Figure 9.1 Management systems employed in the companies.

regarding the entire or a large part of the organization; all other components of the company management system are determined starting from the management system-specific objectives.

c Management systems represent a methodological undertaking, with a very strong specificity, being rigorously structured in decisional, organizational, informational, motivational, etc. elements precisely defined in implementation and functioning stages and phases, causing deep qualitative changes and better company performance.

d Management systems present high innovational content, generating profound and effective changes in all components of the organization management processes and relationships and a renewal of their approaches and utilisation, which is quite different compared with other managerial systems and mechanisms. 


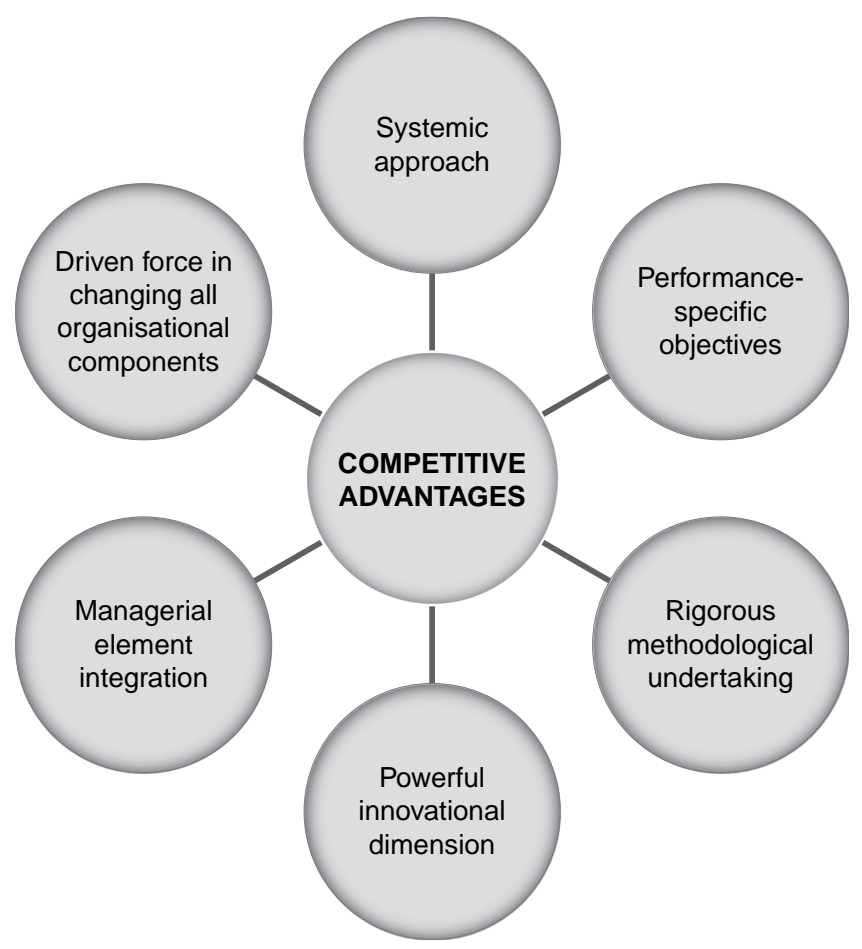

Figure 9.2 Main competitive advantages of the company management systems compared with other methodological approaches.

e Management systems integrate numerous managerial methodological elements that are smaller and less complex (methods, techniques, procedures) and of a different nature (decisional, organizational or informational) that are used in a particular manner, enabling higher company performance.

f Management systems determine deep mutations in all other systems incorporated in the company (technical system, economic system, human system, ecological system, etc.) in their work and performance; management systems are the driving force to change all other elements in the organization.

Management systems are continually improving and renewing under the impact of the organization's exogenous and endogenous evolutions and challenges in all fields: digital, technique, informatic, commercial, financial, human, ecological, social, etc. Every new stage in the development of the society, economy, science, or education demands new managerial approaches and new management systems able to capitalise from the managerial point of view and performance the innovational 
elements of these phases. The valorisation of the innovational elements is faster, larger, and more performant as the new management systems are professionally designed and used in the companies.

The present transition period to the new economy and digitalisation needs - as many specialists have emphasised (see Chapter 2 of this book) radical changes in management and requires innovative company management systems that are quite different from the previous systems. According to our analysis, the company stakeholders-based management system represents such a managerial innovation necessary to organizations in the present and future environments.

\section{Necessity of the Stakeholders-Based Management System}

Our analysis based on the latest economic and managerial evolutions, on the review of numerous management and business studies and on the trends and challenges in companies, allows us to identify several essential elements that demonstrate the necessity to construct a managerial system focused on the company-relevant stakeholders. We call it stakeholdersbased management.

We present the arguments regarding the necessity to use a new stakeholders-based management system in companies (Figure 9.3).

a Companies possess only a part of the resources needed to fulfil their objectives, especially technical, material, and financial resources. Another major part of the necessary resources, especially human, information, and knowledge, is possessed by stakeholders. Also, the company stakeholders comprise significant material resources (suppliers, partners) and financial resources (bankers, investors). All these elements argue the necessity for the company to obtain and use numerous and essential resources from its internal and external stakeholders.

b The company's own resources, as such, do not create value added only because they exist. Company resources generate products, services, value added, and profit only if they are employed by human resources, by the stakeholders. The resources, either the company's own or those of stakeholders, are working and producing value through the knowledge and efforts of both internal (managers, executants, and shareholders) and external stakeholders (clients, suppliers, consultants, designers, researchers, investors, and others). Without the work processes done by company stakeholders inside and outside the organization, resources do not produce anything. This means that it is vital for the company to determine the relevant stakeholders to efficiently use the company resources and their own, in the interest of the organization.

c Company survival and sustainable development depend to a large extent on the organizational stakeholders. Business reality provides 
many examples of companies from the same industry having similar resources but with very different development and performances (productivity, costs, sale, profit, environment protection) because of the differences between their stakeholders and the managerial relationships with them. Relevant stakeholders' quality, intensity of motivation, engagement, creativity, and efforts frequently make the difference between companies' development and results. For this reason, it is necessary to approach and manage the relevant company stakeholders in such a way that they intensively and permanently contribute to the company development, using their own knowledge and other resources to a high level.

d Stakeholders with major influence on the company work and performance are continuously increasing and diversifying in number and quality. At the beginning of industrial development, company management was focused on the organization and shareholders and on its internal activities, mainly making products and services. Gradually, this managerial approach proved not to be very productive and profitable for companies. Organization management has started slowly to pay more attention to the other stakeholder categories: clients, suppliers, and managers. In recent decades, the influence of these stakeholders increased rapidly, as well as the impact of other stakeholder categories: external investors, business partners, designers, consultants, researchers, local communities and competitors. All these evolutions require the company management to continue to enlarge and diversify the stakeholders taken into consideration. Company management should pay attention to the particularities and specific influence and demand of every relevant stakeholder category and to each relevant stakeholder, based on the organization's strategy.

e Stakeholders' interests in the company work and performance and, concomitantly, their capacity to significantly impact them are amplifying step by step. More and more company stakeholders became relevant. Company needs to use more stakeholders' resources (knowledge, raw material, equipment, money, etc.), efforts, and abilities to achieve organization objectives. These elements determine the necessity for the company to deal permanently with relevant stakeholders, taking into consideration their specific interests, requirements, and characteristics. In the company management, relevant stakeholders should be in the central position and approached in specific ways, according to the features of every category of relevant stakeholders and of each relevant stakeholder.

$\mathrm{f}$ A major feature of the present time, characterised by the transition to a knowledge-based economy and digitalisation, is transformation of the knowledge in the most important development resource (see Chapter 2). 


\begin{tabular}{|c|c|}
\hline $\begin{array}{l}\text { 5. Relevant stakeholders' interest } \\
\text { and impact on the company are } \\
\text { enhancing }\end{array}$ & $\begin{array}{l}\text { 6. Company survival and } \\
\text { development need a specific } \\
\text { approach }\end{array}$ \\
\hline $\begin{array}{l}\text { 4. Company-relevant stakeholders } \\
\text { are increasing and diversifying }\end{array}$ & $\begin{array}{l}\text { 7. New types of companies and } \\
\text { business processes centred on the } \\
\text { stakeholders, like ecosystem and } \\
\text { co-opetition, need innovational } \\
\text { management mechanisms }\end{array}$ \\
\hline $\begin{array}{l}\text { 3. Sustainable development and } \\
\text { the company's performance } \\
\text { depend decisively on its relevant } \\
\text { stakeholders }\end{array}$ & $\begin{array}{l}\text { 8. Companies need contributions } \\
\text { of their relevant stakeholders to } \\
\text { competitively face dynamic } \\
\text { organisational and socio-economic } \\
\text { changes }\end{array}$ \\
\hline $\begin{array}{l}\text { 2. Company resources are } \\
\text { producing value added only used } \\
\text { by the stakeholders }\end{array}$ & $\begin{array}{l}\text { 9. Managerial synapses - the new } \\
\text { primary stakeholders management } \\
\text { mechanism - should be } \\
\text { harmonised at the company level }\end{array}$ \\
\hline $\begin{array}{l}\text { 1. Companies need relevant } \\
\text { stakeholders resources }\end{array}$ & $\begin{array}{l}\text { 10. Multidimensional and } \\
\text { sustainable performance could not } \\
\text { be achieved by the company } \\
\text { without relevant stakeholders' deep } \\
\text { and continued involvement }\end{array}$ \\
\hline
\end{tabular}

Figure 9.3 The main necessities for the company stakeholders-based management system.

In the company, knowledge is the main raw material and major production means, product, intellectual capital, and competitive advantage. Human resources knowledge - both tacit and explicit - represents major intellectual capital, which determines, more and more, the company's survival and development. For the activities and performance of every company, the relevant stakeholders' knowledge is essential.

Determination of the company-relevant stakeholders - internal and external - to mobilise, use, and develop the knowledge, with a special preoccupation with tacit knowledge, is a necessity. For this reason, company management must design and use specific managerial approaches, to determine all relevant stakeholders to fully employ the personal and organizational knowledge ${ }^{3}$ for the company development, in a win-win relationship. This is a complex process, as indicated by many studies. ${ }^{4}$

$\mathrm{g}$ In recent decades, in the transition to a knowledge-based economy and digitalisation, new organization forms have been developed, like 
ecosystem, networking company, platform network, and cluster, and new economic processes like co-opetition have also been developed. Stakeholders are playing a decisive role in their creation, development, and performance. We refer, as an example, to the ecosystem, which proliferates quickly and tends to be essential in a new economy.

An ecosystem represents a structure of a multilateral set of partners that interact in order for a focal value proposition to materialise (Adner, 2017). The essential content of an ecosystem is the alignment of activities, actors, positions, and links. This means that an ecosystem involves a set of multiple organizations' stakeholders, which should be managed in specific ways, to generate performance for each of them. A variant of the stakeholders-based management system design, taking into consideration the specificity of the ecosystem, composed of diverse and dispersed partners (Williamson \& De Meyer, 2012), could greatly contribute to the ecosystem's sustainable development and high competitivity.

Co-opetition (Peng, Yen, \& Bourne, 2017), the new emerging economic process, is a result of the intensification of both cooperation and competition in the new economy. As we have already emphasised, cooperation is the third universal principle of the cosmos and is reflected at the level of person, organization, and social-economic environment through "enough" openness and potential for cooperation. Concomitantly, an increasing number of companies that cooperate are in competition relationships. Coopetition is developed in this context, which signifies concomitant deployment of the cooperation and competition processes among the same entities among the involved stakeholders. In order to be efficient for the companies involved and their stakeholders, coopetition needs new specific managerial mechanisms, professionally designed and employed. A stakeholders-based management system, based on win-win negotiation and reasonable compromise, represents such a mechanism.

$h$ The change rate in every field, under the impact of the knowledge revolution, digitalisation, and internationalisation, is rapid. The dynamic character of all systems, despite their nature, size, or localisation, is being enhanced. At the company level, to face the contextual changes, it is necessary the implication of all entities (person or organization), who are interested and have the capacity to significantly influence, this means the company-relevant stakeholders. The stakeholders could significantly contribute to the rapid perception of the different change necessities and initiate the various decisions and actions to construct efficient solutions. To achieve this, there are necessary managerial approaches in the company, with the stakeholders-based management system being one such mechanism. 
i In the 21st century, the stakeholders present numerous elements, which make necessary radical and different managerial approaches in comparison with the previous mechanisms, focused on the manager-subordinate relationship. The managerial synapse, to which we have dedicated two chapters in the book, represents the primary managerial mechanism to fulfil at the individual stakeholder level a new managerial approach for the company-relevant stakeholders. We want to outline that the managerial synapse deals only with the specific relationships between a company manager and a relevant stakeholder from inside or outside the organization. The managerial synapse deals only with work processes in the workplace. Managerial synapses generate superior results when they are correlated, when the involved inputs and outputs are harmonised, and when at the company level they are based on the strategy and the integrative mechanisms. Hence, a specific managerial system is necessary to integrate and correlate at the company level all managerial synapses with relevant internal and external stakeholders.

j To survive and develop, a modern company should achieve multidimensional and sustainable performances. The company could achieve multidimensional performances - commercial, financial, technical, social or ecological - only with the contribution of the internal relevant stakeholders, including managers, stakeholders, and executants, and external relevant stakeholders, including clients, suppliers, bankers, local community, investors, consultants, public administration and other. Sustainable development and performance over many years need continuous and consistent information, knowledge, resources, and relationship of the company's internal and external stakeholders.

A stakeholders-based management system represents a managerial mechanism able to respond to the above-mentioned necessities effectively and efficiently, taking into consideration the challenges and changes at the level of the company, market, and industry and the other contextual elements.

We consider that the 10 arguments presented, which are not exhaustive, demonstrate that a new management system focused on the relevant stakeholders is necessary in companies to be performant using the huge stakeholders potential. The necessity and performance of such a system are amplified by the transition to a knowledge-based economy and knowledge-based company and the rapid digitalisation. A stakeholders-based management system might be a valuable response to the essential problems raised by the well-known specialist Pfeffer (2009):

It's clear that the limits of shareholder capitalism are showing themselves like so many cracks in the ages - old foundation 
of a house. The question is DO the current repair efforts by the senior executives and policy makers signal a lasting return to the stakeholders capitalism - where CEO feel responsible to all constituencies and not just for investors?

\section{Definition of the Company-Relevant Stakeholders-Based Management System}

The definition of the company-relevant stakeholders-based management system has as background a set of premises regarding the company, management, and stakeholders. We present these premises in Table 9.1.

Table 9.1 Premises of the stakeholders-based management system

\begin{tabular}{|c|c|c|}
\hline No. & Premises & Content of Premises \\
\hline 1. & Company is an open system & $\begin{array}{l}\text { The updated company is an open } \\
\text { system, which has many, varied, and } \\
\text { intense relationships (economic, } \\
\text { social, and ecological) with the } \\
\text { environment. In recent decades, the } \\
\text { openness of the company was } \\
\text { enhanced quickly, and this tendency } \\
\text { will continue in the future. }\end{array}$ \\
\hline 2. & $\begin{array}{l}\text { Relevant stakeholders are } \\
\text { essential for the company }\end{array}$ & $\begin{array}{l}\text { Relevant stakeholders are the } \\
\text { determinant factors of the company } \\
\text { creation, work, and development. } \\
\text { Without relevant stakeholders' } \\
\text { contributions, no company could } \\
\text { exist. }\end{array}$ \\
\hline 3. & $\begin{array}{l}\text { Company is a grouping of } \\
\text { stakeholders }\end{array}$ & $\begin{array}{l}\text { A company should and could by } \\
\text { defined as an ensemble of many } \\
\text { different structural and interrelated } \\
\text { stakeholders, which all fulfil the } \\
\text { work processes needed in the } \\
\text { company. }\end{array}$ \\
\hline 4. & $\begin{array}{l}\text { Company and its stakeholders } \\
\text { have multidimensional } \\
\text { objectives }\end{array}$ & $\begin{array}{l}\text { A company, in order to work and be } \\
\text { sustainable, should plan and fulfil, } \\
\text { for itself and its stakeholders, } \\
\text { multidimensional objectives. } \\
\text { Specifically, a company should use } \\
\text { the well-known triple bottom line } \\
\text { (TBL) (Searcy, 2018): economic, } \\
\text { environmental, and social } \\
\text { objectives. }\end{array}$ \\
\hline 5. & $\begin{array}{l}\text { Value shared is the main } \\
\text { economic objective }\end{array}$ & $\begin{array}{l}\text { The main economic objective of the } \\
\text { company should be value shared for } \\
\text { all relevant stakeholders to motivate } \\
\text { them, not profit per se. }\end{array}$ \\
\hline
\end{tabular}


Table 9.1 (Continued)

\begin{tabular}{|c|c|c|}
\hline No. & Premises & Content of Premises \\
\hline 6. & $\begin{array}{l}\text { Company management is } \\
\text { focused on the relevant } \\
\text { stakeholders }\end{array}$ & $\begin{array}{l}\text { Management focusing on the relevant } \\
\text { stakeholders, using specific } \\
\text { approaches, represents a valuable } \\
\text { solution for increasing organization } \\
\text { performance based on the relevant } \\
\text { stakeholders' knowledge, work and } \\
\text { relationships. }\end{array}$ \\
\hline 7. & $\begin{array}{l}\text { Relevant stakeholders } \\
\text { interests, characteristics, and } \\
\text { behaviours are dynamic }\end{array}$ & $\begin{array}{l}\text { The array of relevant stakeholders and } \\
\text { their interests, characteristics, } \\
\text { expectations and motivations is } \\
\text { dynamic, and for this reason, the } \\
\text { company management, together } \\
\text { with the stakeholders, must } \\
\text { constantly evaluate the changes and } \\
\text { take them into consideration. }\end{array}$ \\
\hline 8. & $\begin{array}{l}\text { A company-relevant } \\
\text { stakeholders-based } \\
\text { management system is a } \\
\text { managerial innovation for } \\
\text { management change }\end{array}$ & $\begin{array}{l}\text { A stakeholders-based management } \\
\text { system represents an innovative } \\
\text { managerial variant for the company } \\
\text { and management remodelling to } \\
\text { utilise the huge potential of the } \\
\text { relevant stakeholders, increasing the } \\
\text { company's competitiveness and } \\
\text { sustainability. A stakeholders-based } \\
\text { management system represents a } \\
\text { superior level of maturity in } \\
\text { stakeholders' relationship with } \\
\text { company management. }\end{array}$ \\
\hline
\end{tabular}

The company-relevant stakeholders-based management system consists in all company managerial processes and relationships that predict, organise, coordinate, mobilise, and evaluate the relevant stakeholders' work processes, structured mainly in managerial synapses and based on intense and participative sharing of information, knowledge, and other resources on common and harmonised decisions, actions, and behaviours to achieve sustainable multidimensional interests and objectives of the organization and its relevant stakeholders. Company-relevant stakeholders-based management is emerging as a new management system to utilise the potential of relevant stakeholders in the interest of the organization, to a large extent using emotional intelligence, with beneficial results for all parties involved. In fact, a stakeholders-based management system is a special type of network of internal and external company-relevant stakeholders, in which the managerial synapses play a major role.

In our opinion, the new company-relevant stakeholders-based management system represents the most comprehensive and effective approach to manage a collaborative enterprise. A company-relevant 
stakeholders-based management system is one of the best managerial feedback to collaborative revolution, which is currently taking place, according to Adler, Heckscher, and Prusak (2011). This system is a possible solution to the present trend outlined recently by a group of specialists (Battilana, Pache, Sengul, \& Kimsey, 2019; Ignatius, 2019) regarding the company's change from a simple-minded pursuit of financial gain to consider the interests of all its stakeholders, including employees, customers, communities, and the environment. Companies should focus on four key management practices: setting and monitoring dual goals; structuring the organization to support both goals; hiring and socialising employees to embrace them; and practicing dual-minded leadership.

The company-relevant stakeholders-based management system aims to fulfil two goals:

- Achievement of common purposes of the company and relevant stakeholders' categories, based on common and/or complementary interests. Common objectives vary from one stakeholders' category to another (clients, suppliers, executants, shareholders, etc.) and, often, within each category, from one stakeholder to another. Most frequently, they refer to the direct acquisition of knowledge and human, technical, material, and financial resources, the renewal of product, service, technological, managerial, marketing, and environmental tools, etc., and maintaining and increasing sale, market share, and profit to ensure the sustainability of the organizations involved.

- Establishment of a collaborative mechanism, based on the managerial synapses, to facilitate a higher level of accomplishment - through joint efforts and contributions - of the relevant stakeholders' needs arising from major goals of each of them.

Within the company-relevant stakeholders-based management system, there is a new type of stakeholders-manager relationship, usually structured in managerial synapses, which largely replaces the classic manager-subordinate relationship. The manager-subordinate relationship is based on hierarchical dependence and organizational memberships. In contrast, the new manager-stakeholder relationship is based on the following foundations:

- the interests of each stakeholders in the proper functioning and performance of the company;

- win-win negotiations between the synapse components;

- the capacity of the stakeholders to significantly influence - positively and/or negatively - the activities of the organization; 
- the emotional intelligence of stakeholders, which facilitates interrelations among stakeholders and gives them more consistency;

- the stakeholders' motivation to be useful for the company, contributing to the running of processes and achieving performance, on the basis of a win-win relationship.

Managerial processes and relationships with relevant stakeholders, based on the managerial synapses and guided by a sense of shared purposes, facilitate the committed collaboration in the company, which is beneficial for the parties involved.

Company management processes, modelled through managerial synapses based on win-win negotiations, are powerful managerial processes. This is essential because "firms with strong managerial processes do significantly better on the high metrics such as profitability, growth and productivity" (Sadun, Bloom, \& Van Reenen, 2017).

A stakeholders-based management system combines, concomitantly, the focus on the management processes and relationships with the relevant stakeholders' essential stakes. The company-relevant stakeholders-based management system is a way to move in practice away "from capitalistic to humanistic business" (Dierksmeier, 2016), reflecting the paradigm shift in the field of theory from mechanistic economics toward humanistic economics. In practice, this involves "human purposes" for a company, broadly defined as the focal points (Wicks \& Harrison, 2017).

A company-relevant stakeholders-based management system should be founded on the open strategy, characterised by transparency and inclusion (Hautz, Seidl, \& Whittington, 2017). These two dimensions of the open strategy are essential for the relevant stakeholders' organic integration in the organization's management and for the fulfilment of the company and its major interests, needs, and expectations. A company-relevant stakeholders-based management system is founded on the new business model centred on the relevant stakeholders. ${ }^{5} \mathrm{~A}$ company-relevant stakeholders-based management system could incorporate mainly the elements presented in Figure 9.4.

The managerial synapse is the basic component of the stakeholdersbased management system. It is the essential mechanism to manage the new type of managerial relationships and processes between relevant stakeholders and the company representative. The quality of managerial synapses, reflected in the strong collaboration between both components and in the fulfilment of the common objectives, is determinant for the performances at the workplace level and has a significant influence at the departmental and company levels.

An autonomous relevant stakeholder refers to the company-relevant stakeholders who is not a part - for certain reasons - of the managerial synapse. An autonomous relevant stakeholder has a special relationship with the company not usually a hierarchical relationship - but without 


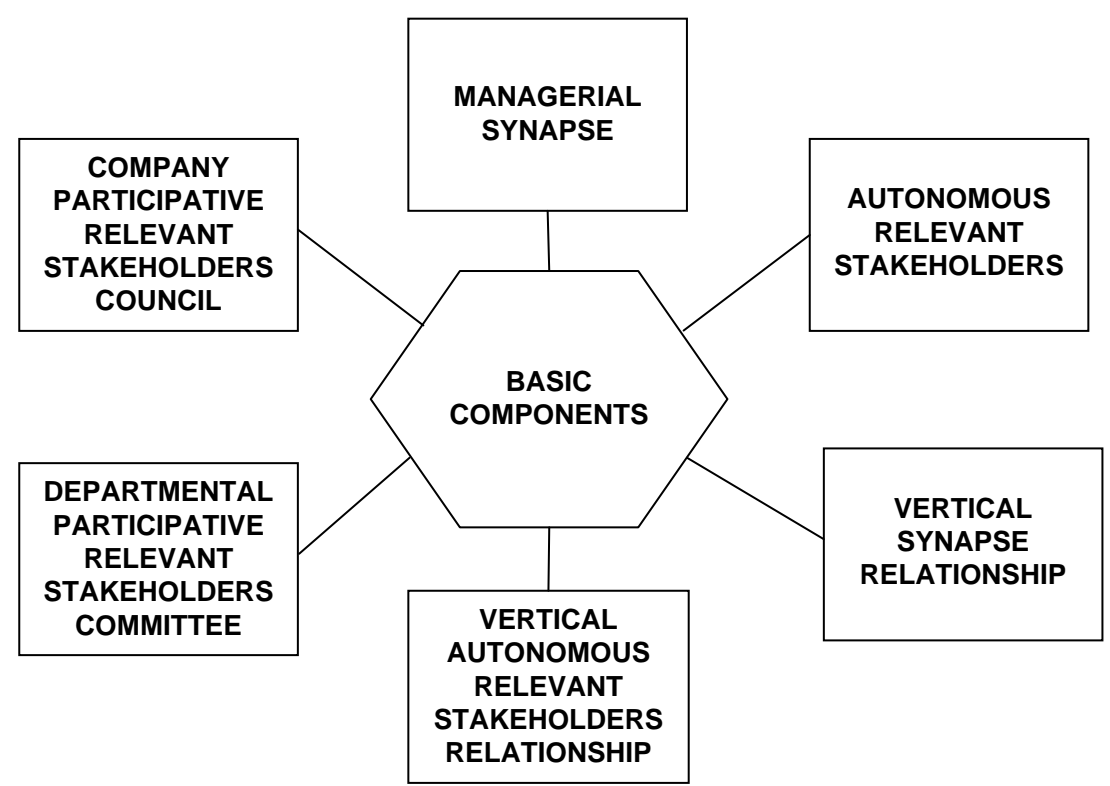

Figure 9.4 Main components of the company-relevant stakeholders-based management system.

being integrated in the synapse. An autonomous relevant stakeholder is not enough influential for the time being on the company work and performance, or is not enough open to be part in the managerial synapse. Also, this category could include the relevant stakeholders who is preparing to be integrated in a managerial synapse.

Each managerial synapse is integrated in the company's organizational structure through a vertical relationship. A company representative in the managerial synapse - a manager or specialist - is subordinated to the manager who is responsible for the activities fulfilled by the managerial synapse components. Similarly, the autonomous relevant stakeholders of the company is integrated in the organization's structure by a special relationship connecting him/her to the manager responsible for the work processes. Characteristics of this relationship depend largely on whether the stakeholders is an employee of the company. Specific for both types of relationship - regarding the managerial synapse and autonomous relevant stakeholders - are the strong collaborative dimension and the significant presence of informal elements. They are effective only if stakeholders' relationships are trustful.

To facilitate the work and the performance of the stakeholders-based management system, it is necessary to have at the company level a participative stakeholders council, which would include representatives of all the relevant stakeholders' categories. Such a council, with periodic 
meetings, has the main purpose to facilitate the remodelling of the company management according to the relevant stakeholders' specificity and evolution, to improve the stakeholders-based management system's work, and to increase the trust of the internal and external stakeholders in the company management and the owner's dedication to consistent and reciprocal beneficial co-work with them, for the sustainable development of all. A company participative stakeholders council should be connected with the administration council of the organization. Close cooperation of the two bodies is mandatory for the company and the relevant stakeholders, having a major influence on the company and the stakeholders' work and performance.

In large companies, where there are many and diversified relevant stakeholders and activities, it could be useful to create at the level of departments or of the main domains a departmental participative relevant stakeholders committee. This organizational body is similar to the previously mentioned council, with the same main objectives but adapted to the specificity of the activities and stakeholders involved. The departmental stakeholders committee is also in a better position to take into consideration the particularities of the domain involved and to contribute to develop it.

Within the stakeholders-based management system it is a hierarchy, but not classic, very authoritarian. A hierarchy is necessary because human beings have a tendency to think and act hierarchically (Zitek \& Tiedens, 2012). It is recommended to be called a "right hierarchy" (Sanner \& Bunderson, 2018), characterised by intense consultation and cooperation, strong informal elements, and team spirit. Such a hierarchy enables initiative, innovation, participative decisions and actions, and flexible approach. An organization in the stakeholders-based management system is recommended to adopt the new participative centralisation type of authority, which has proven useful when overlapping spheres of influence (Adler et al., 2011).

The organizational elements presented should determine the development of the collaborative community around a sense of shared purpose and diversity of the stakeholders' capability, stimulating innovation (Adler et al., 2011). A company-relevant stakeholders-based management system may be employed in two organizational variants:

a Integral stakeholders-based management system, when it incorporates all company-relevant stakeholders - internal and external structured in managerial synapses. This is an optimal variant able to fully utilise the resources and potential of all company-relevant stakeholders. In the case of this organizational variant, the stakeholders-based management system could be designed and implemented as a global company management system.

b Partial stakeholders-based management system, which incorporates integrated in the managerial synapses - only part of the relevant 
stakeholders. Also, it could include some autonomous relevant stakeholders, with special vertical relationships within the company. In the case of this organizational variant, certain relevant stakeholders of the company are approached in the classic manner, without special treatment. A partial stakeholders-based management system might be designed and implemented as a project, taking into consideration the specificity of the stakeholders-based management system. A partial stakeholders-based management system could be used as such for a long time or as a temporary type of organization system during the period of construction of the integral-based management system.

Each company should select the stakeholders organizational variant that is best suited to the organization and its relevant stakeholders.

\section{Main Differences Between the Company-Relevant Stakeholders-Based Management System and "Classic" Company Management Systems}

For a better understanding of the content and specificity of the stakeholders-based management system, we find it useful to point out the main elements that the company-relevant stakeholders-based management system distinguishes itself from classic management systems: management by objectives, management by projects, management by budgets, management by exceptions or management by costs. According to our analysis, the most important differences refer to the issues presented below:

a The areas of stakeholders-based management are substantially amplified by the individuals, processes, relationships, and organizational entities that previously did not form the subject of the organization's management systems or were tangentially related to it and only random.

b The company-relevant stakeholders-based management goes beyond the frame of the company, taking into account the increasing number and importance of external stakeholders, which is reflected in certain parameters, approaches, processes, mechanisms, methods, etc. that are different from those used in the organization's endogenous framing; the stakeholders-based management system is the first company management system that incorporates elements from outside the organization and that are even numerous.

c The information and knowledge generate a considerably higher impact on the content and modalities of stakeholder management processes and relationships, providing them more consistency, complexity, and effectiveness. 
d The personal characteristics of the stakeholders - qualities, knowledge, competencies, emotional intelligence, fairness, sense of responsibility, ability to communicate, desire and capacity to collaborate, team spirit, long term vision, etc. - have a major influence, often decisively, on the content, ways of operationalisation, and effects generated by the new company manager-stakeholder relations, by the managerial synapses.

e In the company-relevant stakeholders-based management system, the informal elements are more numerous and influence to a greater extent the effectiveness of managers' decisions, actions, and behaviours.

f The company-relevant stakeholders-based management system has a stronger motivational dimension because all relevant stakeholders have significant interests in the functioning, development, and competitiveness of the managed organization, whose awareness, consideration, and fulfilment, using managerial synapses, are decisive to achieve the organization's sustainable performance.

$\mathrm{g}$ The participative dimension of the company-relevant stakeholdersbased management system is substantially amplified because it produces intense interaction not only with its own employees, shareholders, and other owners and representatives, but also with many other outside stakeholders-consumers, wholesalers, retailers, suppliers, consultants, designers, researchers, trainers, risk investors and representatives of banks, local government, employers, and professional organizations.

$\mathrm{h}$ The company-relevant stakeholders-based management system is a tense management, because at the level of each company the stakeholders, besides the common interests, have other interests, whose achievement must be allocated time, skills, resources, etc., which are always limited. In addition, in the case of certain stakeholders - usually belonging to the organization or external stakeholders - they may also have competing interests, even if these are less than the common ones, on the basis of which the stakeholder relationship is built.

i Managerial flexibility is intensifying, as a precondition for harmonising a significantly larger and more diverse set of interests, expectations, decisions, actions, and behaviours of company stakeholders.

j The design and work of managerial relationships with individual relevant stakeholders, within managerial synapses are based on the win-win principle, which characterises successful modern negotiations, are rapidly expanding and tend to predominate not only in the organization's relations with external stakeholders, but also with internal ones. Win-win negotiations are likely to contribute substantially to balancing and harmonising the common and particular interests of relevant stakeholders involved. 
$\mathrm{k}$ Protecting the major interests of the company in its relations with the stakeholders, especially the external ones, becomes a major component of the managerial relationships with them, embracing complex and subtle ways of expression, which is only seldom met in classic management.

1 Managers' more extensive, faster, and more accurate information on a broader range of endogenous and exogenous aspects of the company becomes a prerequisite for ensuring the effectiveness and efficiency of managerial processes and relationships with stakeholders. To achieve this, on a large scale and intensively, information and knowledge banks, participative approaches, and integrated informatic systems are used, among other things.

$\mathrm{m}$ The complexity, dynamism, and difficulty of the managerial processes and relationships are greatly amplified, being substantially more demanding for the company's managers, involving more and diversified resources, more creative managerial approaches, and superior efforts and skills.

$\mathrm{n}$ Organizational leadership within a stakeholders-based management system has much greater importance and partially changed content compared to classic leadership, as it has to compensate for the absence of hierarchical dependence on the relationship of the organization's managers with its exogenous stakeholders. Additionally, it has to lead knowledge-based specialists, characterised by a greater spirit of initiative, creativity, informality, and autonomy.

o The company-relevant stakeholders-based management system has a holistic character, superior to classic management, due to the company's approach as an open system, organically linked to many other independent systems that involve external stakeholders.

$\mathrm{p}$ The synergistic long-term effect of the company-relevant stakeholders-based management system is to strengthen the sustainability of the company, due to the contribution of relevant stakeholders and the blending of their strategic interests with the strategic interests of the organization.

q A company-relevant stakeholders-based management system is focused on the achievement of the multidimensional company and stakeholders objectives (economic, social, and ecological) that are different from classic managerial company systems, which, traditionally, are focused mainly on economic objectives.

As a whole, the many highlighted differences demonstrate the high specificity and complexity of the company-relevant stakeholders-based management system compared to classic management systems and contribute to its better perception, understanding, and operationalisation, necessary in the present companies, in the VUCA environment. 


\section{Stakeholders-Based Management System}

\section{Principles of the Company-Relevant Stakeholders-Based Management System}

The foundation, work, development, and performance of the companyrelevant stakeholders-based management system should be based on a set of principles referring to the essential elements involved. The principles are useful in the modelling of the management processes and relationships incorporated by the company-relevant stakeholders-based management system. In Table 9.2, we propose a set of principles, designed in a holistic view, taking into consideration the objectives and specificity of this new company management system, the particularities of the relevant stakeholders, and the recent contextual evolutions, primarily the transition to a knowledge-based economy and digitalisation. In our approach, we employed many recent developments of the management theory and practice and of the company stakeholders approaches.

We want to emphasise that the principles we propose are different from the other stakeholders principles and laws, which we briefly

Table 9.2 Company-relevant stakeholders-based management system principles

\begin{tabular}{|c|c|c|}
\hline No. & Principles & Content of the Principles \\
\hline 1. & $\begin{array}{l}\text { Decisive dependence of the } \\
\text { company work and } \\
\text { performance on the } \\
\text { relevant stakeholders }\end{array}$ & $\begin{array}{l}\text { Every organization depends on many } \\
\text { internal and external stakeholders. In } \\
\text { order to start, develop, and achieve } \\
\text { performance, each company needs to } \\
\text { identify and evaluate the relevant } \\
\text { stakeholders (managers, specialists, } \\
\text { customers, suppliers, investors, } \\
\text { bankers or other) and to integrate } \\
\text { them in special managerial } \\
\text { mechanisms, beneficial for the relevant } \\
\text { stakeholders and the organization. The } \\
\text { company-relevant stakeholders-based } \\
\text { management system is such a } \\
\text { mechanism and specially designed. }\end{array}$ \\
\hline 2. & $\begin{array}{l}\text { Multidimensional objectives } \\
\text { of the company-relevant } \\
\text { stakeholders-based } \\
\text { management system and } \\
\text { the relevant stakeholders }\end{array}$ & $\begin{array}{l}\text { Objectives to be achieved by the } \\
\text { company and its relevant stakeholders } \\
\text { in the stakeholders-based management } \\
\text { system should be multidimensional } \\
\text { (economic, social, ecologic). } \\
\text { Objectives should reflect the main } \\
\text { interests and necessities of the } \\
\text { company and relevant stakeholders. } \\
\text { They should be defined carefully, } \\
\text { reflecting the realities, and be } \\
\text { equilibrated from the company's and } \\
\text { relevant stakeholders' points of view. }\end{array}$ \\
\hline
\end{tabular}


Table 9.2 (Continued)

\begin{tabular}{|c|c|c|}
\hline No. & Principles & Content of the Principles \\
\hline 3. & $\begin{array}{l}\text { Constant individual and } \\
\text { organizational cooperation }\end{array}$ & $\begin{array}{l}\text { The company-relevant stakeholders- } \\
\text { based management system's } \\
\text { foundation, work, development, and } \\
\text { performance are based on the } \\
\text { permanent cooperation between } \\
\text { relevant stakeholders and company } \\
\text { managers within the system at the level } \\
\text { of managerial synapses, vertical } \\
\text { stakeholders' relationships, company } \\
\text { stakeholders council, departmental } \\
\text { committees, and other components. } \\
\text { Cooperation has a triple dimension } \\
\text { (decisional, actional, and } \\
\text { behavioural)- that is tightly } \\
\text { interrelated. Cooperation should be at } \\
\text { both the individual and organizational } \\
\text { levels and is very complex, with the } \\
\text { formal company elements (company } \\
\text { plans, job description, organigram, } \\
\text { etc.) being combined with informal } \\
\text { approaches. Components of the } \\
\text { company-relevant stakeholders-based } \\
\text { management system require } \\
\text { cooperating intensively also with the } \\
\text { other components of the company, } \\
\text { with the organization's external } \\
\text { relevant stakeholders, and with any } \\
\text { other interested entities. All } \\
\text { cooperation processes and } \\
\text { relationships should be subordinated } \\
\text { to the achievement of the common } \\
\text { multidimensional objectives. }\end{array}$ \\
\hline 4. & $\begin{array}{l}\text { Harmonisation of the } \\
\text { company and relevant } \\
\text { stakeholders interests and } \\
\text { stakes }\end{array}$ & $\begin{array}{l}\text { The company-relevant stakeholders- } \\
\text { based management system, in order to } \\
\text { work and be performant, should } \\
\text { harmonise the main interests and } \\
\text { stakes of both the company and the } \\
\text { relevant stakeholders. Harmonisation } \\
\text { of the interests and stakes is necessary } \\
\text { to be done permanently, starting with } \\
\text { establishing the objectives and } \\
\text { finishing with the share of outputs } \\
\text { between the company and relevant } \\
\text { stakeholders. This represents a } \\
\text { precondition for the significant } \\
\text { implication and efforts from the } \\
\text { relevant stakeholders and the } \\
\text { company's managers. }\end{array}$ \\
\hline
\end{tabular}


Table 9.2 (Continued)

\begin{tabular}{|c|c|c|}
\hline No. & Principles & Content of the Principles \\
\hline 5. & $\begin{array}{l}\text { Win-win negotiations and } \\
\text { relationships between } \\
\text { company and relevant } \\
\text { stakeholders }\end{array}$ & $\begin{array}{l}\text { The key element in the construction of } \\
\text { managerial synapses and of the } \\
\text { ensemble of relationships within the } \\
\text { company-relevant stakeholders-based } \\
\text { management system is win-win } \\
\text { negotiation between company } \\
\text { managers and relevant stakeholders. } \\
\text { Win-win negotiation facilitates } \\
\text { formulation of the company's and } \\
\text { relevant stakeholders' common } \\
\text { objectives. It creates enabling premises } \\
\text { and a climate for the next joint } \\
\text { activities for the development of } \\
\text { reciprocity and feedback. }\end{array}$ \\
\hline 6. & $\begin{array}{l}\text { Intense motivation of the } \\
\text { relevant stakeholders and } \\
\text { company managers }\end{array}$ & $\begin{array}{l}\text { A milestone of the company-relevant } \\
\text { stakeholders-based management } \\
\text { system is the constant motivation of } \\
\text { company managers and relevant } \\
\text { stakeholders to fully employ their } \\
\text { knowledge, other resources, and } \\
\text { potential for increasing the company's } \\
\text { and stakeholders' development and } \\
\text { performance. Taking into } \\
\text { consideration the company's and } \\
\text { stakeholders' essential interests, } \\
\text { reflected in common objectives, use of } \\
\text { win-win negotiation; planning from } \\
\text { the beginning of the work period, of } \\
\text { the ways to share the economic and } \\
\text { social outputs; permanent } \\
\text { communication and consultation; } \\
\text { regular use of positive motivation; } \\
\text { permanent preoccupation with fairness } \\
\text { and equilibrium of interests; and } \\
\text { development of an open, innovative, } \\
\text { and constructive culture in the } \\
\text { company, are approaches and means } \\
\text { with powerful motivational impact on } \\
\text { the relevant stakeholders and company } \\
\text { managers and specialists. }\end{array}$ \\
\hline 7. & $\begin{array}{l}\text { Harmonisation of the } \\
\text { company's and relevant } \\
\text { stakeholders' decisions, } \\
\text { actions, and behaviours }\end{array}$ & $\begin{array}{l}\text { Decisions, actions, and behaviours, } \\
\text { through which the company-relevant } \\
\text { stakeholders-based management } \\
\text { system works, are permanently } \\
\text { harmonised at the level of managerial } \\
\text { synapses and the entire company } \\
\text { system. Tasks, roles, competencies, } \\
\text { and responsibilities of the company }\end{array}$ \\
\hline
\end{tabular}


Table 9.2 (Continued)

\begin{tabular}{l} 
No. $\quad$ Principles \\
\hline Achievement of a reasonable \\
and sustainable \\
compromise
\end{tabular}

9. Permanent communication, consultation, and connectivity of the company managers with relevant stakeholders

managers and the relevant

stakeholders, at the level of managerial synapses and the whole system, are defined in a specific manner, enabling harmonisation in all aspects. Relevant stakeholders and company managers, using permanent communication and consultation, correlate all work processes within the company-relevant stakeholders-based management system, avoiding dysfunctionalities and conflicts and increasing mutual understanding, cooperation, and synergy at the levels of the workplace, domains, and the entire company and other stakeholders entities.

Relevant company stakeholders and the company often have different interests, approaches, or perceptions. To avoid divergences, dysfunctionalities, or conflicts, they should be eliminated or drastically reduced. A major way to do this is to look for reasonable compromise. Essentially, a reasonable compromise means a solution, an approach, or an agreement that is not optimum for any participant involved but that represents an acceptable result for all parties, taking into consideration the elements most important for each of them. The reasonable compromise should be made in a sustainable perspective, contributing to continuation of the beneficial stakeholder-company relationships in the long term.

The creation and work of the managerial synapses and of all relationships within the stakeholders-based management system are determined by the information and knowledge exchanged within the system. Common objectives, win-win negotiations, and harmonisation of the stakeholders' decisions, actions, and behaviours could not be achieved without constant exchange of information and knowledge, openness 
Table 9.2 (Continued)

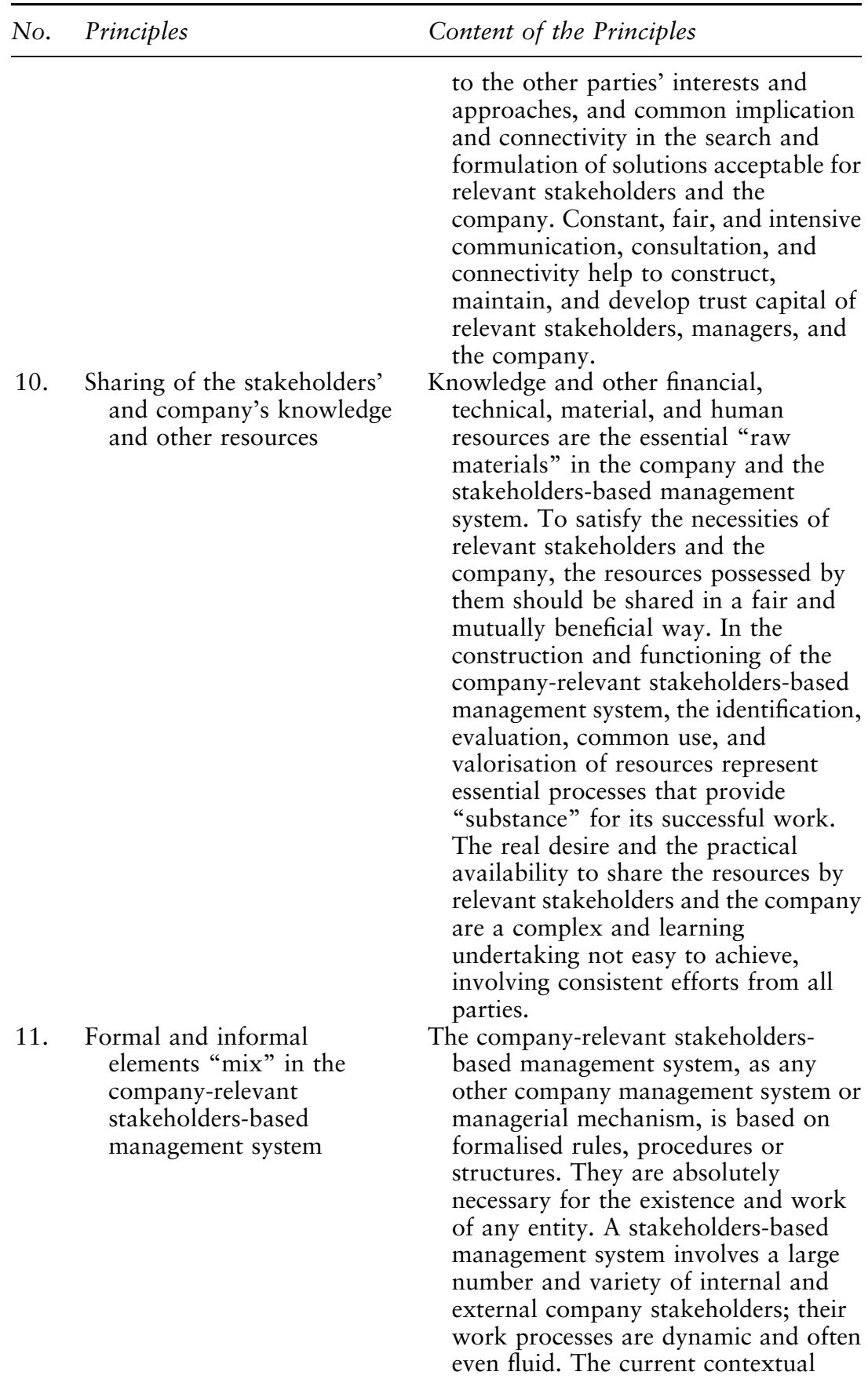


Table 9.2 (Continued)

\begin{tabular}{|c|c|c|}
\hline No. & Principles & Content of the Principles \\
\hline 12. & $\begin{array}{l}\text { Sustainable approach and } \\
\text { performance of the } \\
\text { company and the relevant } \\
\text { stakeholders }\end{array}$ & $\begin{array}{l}\text { conditions are changing fast and not } \\
\text { always in a predictable way. For these } \\
\text { reasons, the relevant stakeholders and } \\
\text { the company managers need to be } \\
\text { flexible, creative, and entrepreneurial. } \\
\text { All these positive features are possible } \\
\text { only if the formalised managerial } \\
\text { elements are reduced to the essentials, } \\
\text { leaving enough decisional and } \\
\text { operational autonomy for the informal } \\
\text { approaches. The present tendencies in } \\
\text { the management of almost any type of } \\
\text { organization is to increase the use of } \\
\text { the informal elements, enabling fast } \\
\text { feedback, flexible approaches, and } \\
\text { performant innovations. } \\
\text { The company-relevant stakeholders- } \\
\text { based management system is a long- } \\
\text { term oriented mechanism, aiming at } \\
\text { multidimensional economic, social, } \\
\text { and ecological performances for the } \\
\text { company and the relevant } \\
\text { stakeholders. Through the open } \\
\text { strategy and in a transparent and } \\
\text { inclusive manner involving relevant } \\
\text { stakeholders, plans are made for the } \\
\text { company's fundamental objectives and } \\
\text { the main modalities to achieve them in } \\
\text { the next } 3 \text {-5 years. All work processes } \\
\text { at the level of managerial synapses and } \\
\text { the whole system are designed and } \\
\text { implemented focused on the common } \\
\text { multidimensional long-term objectives, } \\
\text { which are win-win negotiated. The } \\
\text { fundamental implication of the } \\
\text { relevant stakeholders (clients, } \\
\text { suppliers, managers, investors, } \\
\text { consultants, and other) in using the } \\
\text { managerial synapses and other } \\
\text { elements of the stakeholders-based } \\
\text { management system in all managerial } \\
\text { and execution processes represents a } \\
\text { major contribution to the sustainable } \\
\text { approach and performance and a } \\
\text { guarantee of achieving them. }\end{array}$ \\
\hline
\end{tabular}


discussed in Chapter 4, Section 4.5. Without a doubt, we might find certain resemblances, but the essential content of the principles is not the same and could not be the same, because they deal with two new stakeholders managerial mechanisms:

- managerial synapse, at the level of manager-relevant stakeholder relationships;

- a stakeholders-based management system, at the company level.

Also, our approach to relevant stakeholders, to whom the principles refer, is not the same with previous approaches regarding the salient stakeholders, the primary stakeholders, and others.

The principles included in Table 9.2, taken together, represent a system. All should be used in the designing, working, and developing of the company-relevant stakeholders-based management system, taking into consideration their interdependence and complementarity. It is mandatory that every principle be considered and used. Ignoring one of them generates negative effects on the company-relevant stakeholdersbased management system's functionality and on the company's and relevant stakeholders' dedication to the common objectives and the sustainable multidimensional performances.

\section{Multiple Advantages of the New System for the Company and Relevant Stakeholders}

The company-relevant stakeholders-based management system responds to a large extent to the 25 management's great challenges, formulated in 2009 by the "Renegade brigade" of academics, CEOs, consultants, entrepreneurs, and venture capitalists (Hamel, 2009). Among these, we mention the following: ensure that the work of management serves a higher purpose, reduce fear and increase trust, expand and exploit diversity, expand the scope of employee autonomy, share the work of setting direction, redefine the work of the leadership, reinvent strategymaking as an emergent process, retool management for the open world, and destructure and disaggregate the organization. The stakeholdersbased management system has consistent economic, humanistic, and ecological content. In Figure 9.5, we formulate synthetically, in a more pragmatic manner, the main advantages of the stakeholders-based management system, its multiple beneficial effects on the company, and its relevant stakeholders.

The advantage of higher motivation is essential, and a recent study published in Harvard Business Review provides a supplementary argument: "Numerous studies show that close to two-thirds of US employees are bored, detached, or jaded and ready to sabotage plans, projects, and other people" (McKee, 2017). It is very important to stress this amazing 


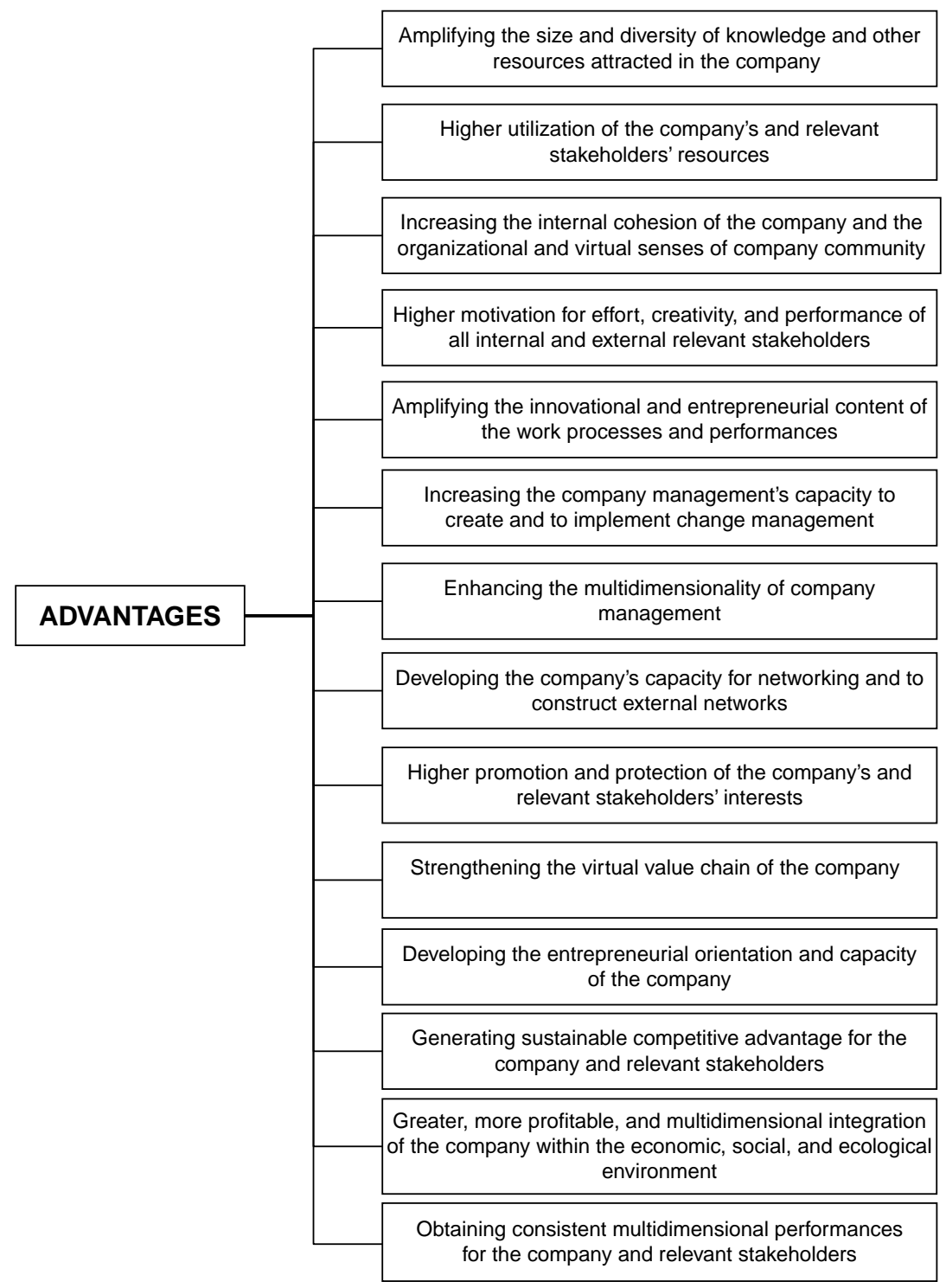

Figure 9.5 Main advantages of the company-relevant stakeholders-based management system.

situation in USA, where is practiced one of the most performant company management in the world.

Besides the numerous and consistent advantages, the companyrelevant stakeholders-based management system has several limits: 
- the dependence of its operation and performances on a large and heterogeneous number of relevant stakeholders, some of whom are located and operate outside the organization

- the high complexity of the management system, generated mainly by many and different relevant stakeholders with multiple and, often, contradictory interests

- major difficulties in implementing the company-relevant stakeholdersbased management system due to the many and diversified internal and external variables involved

- the relatively long duration of full implementation of the companyrelevant stakeholders-based management system, determined by the previous limits

- high building and operationalisation costs of the new management system, due to the larger scope, represented by all relevant stakeholders, and the need to consider and satisfy the interests of numerous stakeholders, many of them with great impact on the organization.

The advantages of the company-relevant stakeholders-based management system prevail over its limits, reflected by the substantial gain of functionality, competitiveness, and sustainability for the company and its relevant stakeholders. In this context, the following statement of the German specialists Bottenberg, Tuschke, and Flickinger (2016) is pertinent: "Acknowledging potential problems arising from stakeholders orientation, as well as its unique benefits, we call for a modern stakeholders value system".

\section{Comparative Approach of the Company-Relevant Stakeholders-Based Management System with the Stakeholders' Engagement}

Stakeholders' engagement has been the main organization management feedback to the necessity to reconsider the relationships with the stakeholders, to use to a larger extent their resources and potential, and to face their challenges. There are many different approaches of stakeholders' engagement, which could be grouped into two categories:

- stakeholders' engagement at the company level;

- stakeholders' engagement at the level of a management project, which is more developed and used than the previous category.

Definitions of stakeholders' engagement also differ to a certain extent. We present two definitions of stakeholders' engagement, the first more general and the second focused on the stakeholders' engagement in project management. According to the definition elaborated by specialists from the 
Royal Institution of Chartered Surveyors (RICS) in Great Britain, "engagement signifies all the things we might do with stakeholders: consult, listen, understand, communicate, influence, negotiate, etc. with the broader objectives of satisfying their needs, gaining approval and support or at least minimizing their opposition or obstruction" (MacNicol, Giffin, \& Mansell, 2014). Another specialist referring to the projects defines stakeholders' engagement as "the process used by an organization to engage relevant stakeholders for a purpose to achieve accepted outcomes" (Worsley, 2016).

There are also many sets of principles of stakeholders' engagement, most dealing with stakeholders' engagement in project management. The differences between them are quite substantial, not only in number (6-10) but also, and especially, in content. We present two variants, which are quite different in the number of principles and content.

The first variant was elaborated by the mentioned specialists from the RICS with the definition of stakeholders' engagement. They formulated 10 engagement principles:

- communicate

- consult early and often

- remember they are only human

- plan it

- relationships are the key

- simple, but not easy

- just part of managing risk

- compromise

- understand what success is

- take responsibility (MacNicol et al., 2014).

Another example is the six principles of stakeholders' engagement formulated by Worsley (2016) especially for projects:

- Stakeholders should have a say in decisions that affect them.

- Stakeholders' participation includes the promise that their contributions will influence decisions and they are told how.

- Stakeholders' engagement seeks out those potentially affected by, or interested in, a decision.

- Stakeholders' engagement seeks input on how they may wish to participate.

- Stakeholders' engagement provides information, time, and space to allow stakeholders to participate in a meaningful way.

- It never hurts to be polite.

Other specialists have also elaborated different principles of stakeholders' engagement (Cundy et al., 2013; Gautrey, 2013; Lawrence, 2017). Many 
specialists have noted the limits of stakeholders' engagement and the necessity to have another approach. For example, Horner and Wilmshurst (2016) noted that "whilst have been instances of successful stakeholders engagement, evidence suggests that the most engagement exercises are for the purpose of reputation and stakeholders management".

Lawrence (2017) emphasised, based on several studies, "[it] is clear that simply engaging with stakeholders is insufficient to build a successful stakeholder strategy. Companies consider as the focal entity in a relationship, also need to actively communicate with stakeholders and manage their relationships".

Stakeholders' engagement has several important contributions in the management field:

a It represents the best-known organization management approach, trying to improve and develop relationships with important stakeholders.

b It develops a few specific principles, approaches, methods, and techniques to deal with the stakeholders, especially for the management project.

c It contributes to better relationships between some important stakeholders and the organization, mainly for the project.

d It focuses largely on the external stakeholders, revealing their major impact on the organization's work and performance.

e It reveals the necessity and possibility to deal specifically with the important stakeholders and to pay special attention to them by the company managers, scientists, and media.

In Table 9.3, we present the results of a comparative analysis of the stakeholders-based management system and stakeholders' engagement, which help to understand the differences between these two approaches of the company stakeholders and their perspectives.

Differences between the two approaches represent valuable arguments to use in company management, the new company-relevant stakeholdersbased management system.

\section{Necessity and Benefits of the Company-Relevant \\ Stakeholders-Based Management System in the COVID-19 Pandemic and Post-Pandemic Contexts}

In the authors' opinion, the company-relevant stakeholders-based management system is necessary in companies, especially medium and large companies in the context of the COVID-19 pandemic. The necessities are generated by the many and fundamental changes that have occurred during the past year because of this pandemic. They could be divided into two categories: 
Table 9.3 Main differences between the company-relevant stakeholders-based management system and stakeholders' engagement

\begin{tabular}{|c|c|c|c|}
\hline No. & Criteria & $\begin{array}{l}\text { Company-Relevant } \\
\text { Stakeholders-Based } \\
\text { Management System }\end{array}$ & $\begin{array}{l}\text { Stakeholders' } \\
\text { Engagement }\end{array}$ \\
\hline 1. & Objectives & $\begin{array}{l}\text { Multidimensional for } \\
\text { company and } \\
\text { relevant } \\
\text { stakeholders }\end{array}$ & $\begin{array}{l}\text { Classic targets, mainly } \\
\text { economic, usually } \\
\text { only for the } \\
\text { company or project }\end{array}$ \\
\hline 2. & Components & $\begin{array}{l}\text { All or most of the } \\
\text { company-relevant } \\
\text { stakeholders }\end{array}$ & $\begin{array}{l}\text { Some of the important } \\
\text { stakeholders, often } \\
\text { only the } \\
\text { stakeholders } \\
\text { "creating" tensions } \\
\text { or very influential on } \\
\text { the company }\end{array}$ \\
\hline 3. & $\begin{array}{l}\text { Background of the } \\
\text { stakeholders-organi- } \\
\text { zation relationships }\end{array}$ & $\begin{array}{l}\text { Win-win negotiation, } \\
\text { cooperative } \\
\text { approach }\end{array}$ & $\begin{array}{l}\text { Organizational } \\
\text { authority, often of a } \\
\text { hierarchical nature }\end{array}$ \\
\hline 4. & Communication & $\begin{array}{l}\text { Comprehensive, } \\
\text { intensive, often } \\
\text { dialogic } \\
\text { communication }\end{array}$ & $\begin{array}{l}\text { Selective } \\
\text { communication, } \\
\text { focused on the } \\
\text { "problems" between } \\
\text { the organization and } \\
\text { certain stakeholders }\end{array}$ \\
\hline 5. & $\begin{array}{l}\text { Specific } \\
\text { organizational-stake- } \\
\text { holders mechanisms }\end{array}$ & $\begin{array}{l}\text { Managerial synapses } \\
\text { and stakeholders- } \\
\text { based management } \\
\text { system }\end{array}$ & $\longrightarrow$ \\
\hline 6. & Motivation & $\begin{array}{l}\text { Intense and permanent } \\
\text { motivation based on } \\
\text { win-win negotiation } \\
\text { and use of a wide } \\
\text { array of motivation } \\
\text { for both the } \\
\text { company and } \\
\text { relevant } \\
\text { stakeholders }\end{array}$ & $\begin{array}{l}\text { Specific temporary } \\
\text { motivation to solve } \\
\text { the relevant } \\
\text { stakeholders' } \\
\text { problems with the } \\
\text { company }\end{array}$ \\
\hline 7. & Entity where utilised & $\begin{array}{l}\text { Company and any } \\
\text { other type of } \\
\text { organization }\end{array}$ & $\begin{array}{l}\text { Project management } \\
\text { (the most frequent) } \\
\text { and large companies }\end{array}$ \\
\hline 8. & Duration & $\begin{array}{l}\text { Permanent, with } \\
\text { periodic } \\
\text { (recommended } \\
\text { yearly) review }\end{array}$ & $\begin{array}{l}\text { Usually temporary } \\
\text { until the project is } \\
\text { finished or the } \\
\text { company has solved } \\
\text { the specific relevant- } \\
\text { stakeholders } \\
\text { problem }\end{array}$ \\
\hline
\end{tabular}


Table 9.3 (Continued)

\begin{tabular}{|c|c|c|c|}
\hline No. & Criteria & $\begin{array}{l}\text { Company-Relevant } \\
\text { Stakeholders-Based } \\
\text { Management System }\end{array}$ & $\begin{array}{l}\text { Stakeholders' } \\
\text { Engagement }\end{array}$ \\
\hline 9. & Resources considered & $\begin{array}{l}\text { All or most of the } \\
\text { company's and } \\
\text { relevant } \\
\text { stakeholders' } \\
\text { resources; } \\
\text { knowledge is often } \\
\text { considered the most } \\
\text { important resource } \\
\text { to be shared }\end{array}$ & $\begin{array}{l}\text { Some resources, } \\
\text { selectively } \\
\text { considered, of the } \\
\text { company or } \\
\text { important } \\
\text { stakeholders; there } \\
\text { are relatively } \\
\text { frequent situations } \\
\text { regarding the non- } \\
\text { market stakeholders, } \\
\text { when their resources } \\
\text { are not taken into } \\
\text { consideration }\end{array}$ \\
\hline 10. & Organizational culture & $\begin{array}{l}\text { Specific organizational } \\
\text { culture is developed } \\
\text { - open, inclusive, } \\
\text { intensely } \\
\text { communicative, } \\
\text { innovative, } \\
\text { entrepreneurial, and } \\
\text { participative }\end{array}$ & $\begin{array}{l}\text { Organizational culture } \\
\text { is not a central } \\
\text { element in the } \\
\text { engagement } \\
\text { approach, } \\
\text { sometimes being } \\
\text { developed, for } \\
\text { influential groups of } \\
\text { stakeholders or } \\
\text { specific sub-cultures }\end{array}$ \\
\hline 11. & Complexity & $\begin{array}{l}\text { Usually high or } \\
\text { average-high } \\
\text { complexity }\end{array}$ & $\begin{array}{l}\text { Usually average or low } \\
\text { complexity, } \\
\text { depending on the } \\
\text { number of } \\
\text { stakeholders } \\
\text { considered and the } \\
\text { intensity of the } \\
\text { relationships } \\
\text { between the project } \\
\text { and company, on the } \\
\text { one hand, and the } \\
\text { stakeholders, on the } \\
\text { other hand }\end{array}$ \\
\hline 12. & Cost & $\begin{array}{l}\text { Substantial cost, } \\
\text { necessary to } \\
\text { construct and to } \\
\text { work a } \\
\text { comprehensive } \\
\text { specific management } \\
\text { system with relevant } \\
\text { stakeholders }\end{array}$ & $\begin{array}{l}\text { Usually low cost, } \\
\text { necessary to solve } \\
\text { limited relevant- } \\
\text { stakeholders } \\
\text { problems }\end{array}$ \\
\hline
\end{tabular}


Table 9.3 (Continued)

\begin{tabular}{|c|c|c|c|}
\hline No. & Criteria & $\begin{array}{l}\text { Company-Relevant } \\
\text { Stakeholders-Based } \\
\text { Management System }\end{array}$ & $\begin{array}{l}\text { Stakeholders' } \\
\text { Engagement }\end{array}$ \\
\hline 13. & Specific strategy & $\begin{array}{l}\text { Always based on the } \\
\text { specific strategy, } \\
\text { which should be } \\
\text { open, inclusive, and } \\
\text { transparent, focused } \\
\text { on the construction } \\
\text { and work of the } \\
\text { stakeholders-based } \\
\text { management system }\end{array}$ & $\begin{array}{l}\text { Rarely, the company } \\
\text { approach of the } \\
\text { important } \\
\text { stakeholders } \\
\text { represents the target } \\
\text { of a special strategy; } \\
\text { usually, the } \\
\text { company utilises } \\
\text { current or short- } \\
\text { term approaches }\end{array}$ \\
\hline 14. & Performance & $\begin{array}{l}\text { Multidimensional } \\
\text { sustainable } \\
\text { performance } \\
\text { (economic, social, } \\
\text { and ecological) for } \\
\text { both the company } \\
\text { and the relevant } \\
\text { stakeholders }\end{array}$ & $\begin{array}{l}\text { Specific results for a } \\
\text { group of } \\
\text { stakeholders and/or } \\
\text { company; sometimes } \\
\text { the results refer to } \\
\text { the solving of certain } \\
\text { problems (increasing } \\
\text { the support of the } \\
\text { company activists or } \\
\text { minimising } \\
\text { communities' } \\
\text { resistance to certain } \\
\text { company initiatives, } \\
\text { and other times } \\
\text { referring to } \\
\text { obtaining a specific } \\
\text { performance) }\end{array}$ \\
\hline
\end{tabular}

a Contextual necessities, represented by threats and difficulties determined by the negative impact of the COVID-19 pandemic in the company environment. According to the analysis of many specialists (Boston Consulting Group, 2020; Carlsson-Szlezac, Reeves, \& Swartz, 2020; Chaturvedi, Dey, \& Singh, 2020; Gjaja, Fæste, Hansell, \& Hohner, 2020; Heichler, 2020; King, Wald, \& Manly, 2020; Narayandas, Hebbar, \& Li, 2020; Nicolescu, Popa, \& Dumitrascu, 2020; Radjou, 2020; Romeo, Moukanas, \& Rung, 2020; Waldron \& Wetherbe, 2020), the most frequent and important are the following:

- Substantial decrease or delay in the supply with many raw materials, spare parts, half-finished goods, finished goods, services, etc.

- Great reduction of the direct demand for products and services in many areas (tourism, transportation, sports, shows, restaurants, hotels, etc.) 
- Increased risk of the delay and/or blockage for economic and social projects already started, especially those financed from public and state funds

- Reduction of the indirect demand (industry, service, and trade) for numerous products and services, caused by the previous changes

- Substantial and even Brownian fluctuation in the prices and orders for certain product categories (petrol, drugs, medical protection equipment and substances, etc.).

- Significant decrease and reorientation of the alternative finance (stock exchange, venture capital, investment company, etc.) and from banks

- Notable and partially unexpected changes in behaviour of the individual and institutional consumers caused by the previous shifts, reflected in modifications in the size and frequency of the demand for products and services, determined by changes in direct and indirect consumption, by "buffer" stocks, etc.

These contextual changes cause problems in the organization's relationships with all major external stakeholders: clients, suppliers, banks, local communities, consultants, designers, local authorities. There are decreases, tensions, and even blockages or cancellations in the work with external stakeholders, which have a major negative impact on them and on the company's activity and performance.

b Organizational necessities, represented by the major changes induced by the COVID-19 pandemic in companies, occur at three levels:

- Workplace - social distance, work from home, telework, hybrid communication, work online, etc.

- Department - hybrid team, hybrid communication, online meetings, jobs lost, incohesive team, etc.

- Organizational level - decrease of sales, profit, jobs, etc.; financial difficulties and/or blockage; tense organizational culture; etc.

The changes and difficulties involve all relevant internal stakeholders managers, executants, and shareholders - and some external stakeholders, most often consumers, intermediaries, suppliers, banks, local communities, and/or local authorities. In our opinion, these major internal and external threats and difficulties represent arguments for the new managerial mechanisms in companies to be able to face them and to rapidly recover and relaunch their activities and performances. The company-relevant stakeholders-based management system, by its vision and characteristics, could be one of them. The use of this system in a company generates many benefits, which we divide into two categories: 
- First are the benefits at the level of the company relationship with each relevant stakeholder. We indicated these benefits in Chapter 5, Section 5.10.

- Second are the synergic benefits at the level of the entire company and the ensemble of relevant stakeholders:

- Faster and more durable recovery of the relationships with the company-relevant stakeholders by eliminating or decreasing the blockages or bottlenecks;

- Facilitation of new external stakeholders identification with more enabling potential for the company;

- Boosts the company's integration in the networks using the upstream- and downstream-relevant stakeholders;

- Provides a new business model that is highly motivational, flexible, and innovative and that is able to attract more knowledge, information, and financial and material resources from the internal and external company stakeholders, and to improve organizational functionality;

- Faster return of the company to the size of sale and profit from the period before the COVID-19 pandemic crisis;

- Strengthening and increase of the company's sustainability;

- Strengthening and increase of the external company-relevant stakeholders' sustainability;

- Better positioning of the company for capitalisation of the opportunities offered by the transition to a smart economy and digital transformation.

Based on the previous elements and, especially, the benefits for the company and relevant stakeholders, we strongly recommend the use of the company-relevant stakeholders-based management system in the complex context of the COVID-19 period and post-period.

\section{Notes}

1 We present our approach of the management functions. (See Nicolescu, O., \& Verboncu, I., 2008. Fundamentele managementului organizației. București, România: Editura Universitară). In the management literature are many different variants. See for example Longenecker, J. G., \&. Pringle, C. D., 1981. Management. Columbus, OH: Charles E. Merrill Publishing; Griffin, W. R, 2012. Management: Principles and practice (11th ed.). Mason, OH: Thomson South-Western.

2 See more in Nicolescu, O., \& Verboncu, I. (2008). Fundamentele Managementului Organizației. București, România: Editura Universitară.

3 In this managerial undertaking is very useful to use the new concepts, approaches, tools, provided by the new management discipline - knowledgebased management (See for example Nicolescu, O., \& Nicolescu, C., 2011. 
Organizaţia şi managementul bazate pe cunoştinţe. București, România: Pro Universitaria).

4 See for example Hutzschenreuter, T., \& Horstkotte, J. (2010). Knowledge transfer to partners: A firm level perspective. Journal of Knowledge Management, 14(3), 428-448. https://doi.org/10.1108/13673271011050148; Ma, Z., \& Yu, K. (2010). Research paradigms of contemporary knowledge management studies: 1998-2007. Journal of Knowledge Management, 14(2) 175-189. https://doi.org/10.1108/13673271011032337; Nicolescu, O., \& Nicolescu, C. (2011). Organizaţia şi managementul bazate pe cunoştinţe. București, România: Pro Universitaria.

5 We will present this new business model later in.

\section{References}

Adler, P., Heckscher, C., \& Prusak, L. (2011). Building a collaborative enterprise. Harvard Business Review, 89(7/8), 94-101.

Adner, R. (2017). Ecosystem as structure: An actionable construct for strategy. Journal of Management, 43(1), 39-58. doi:10.1177/0149206316678451

Battilana, J., Pache, A.-C., Sengul, M., \& Kimsey, M. (2019). The dual-purpose playbook. Harvard Business Review, 97(2), 124-133.

Boston Consulting Group. (2020). COVID-19 BCG perspectives series: Facts, scenarios and actions for leaders. Retrieved from https://mediapublications.bcg.com/BCG-COVID-19-BCG-Perspectives-Version13.pdf

Bottenberg, K., Tuschke, A., \& Flickinger M. (2016). Corporate governance between shareholder and stakeholder orientation: Lessons from Germany. Journal of Management Inquiry, 26(2), 165-180. doi:10.1177/105649261 6672942

Carlsson-Szlezac, P., Reeves M., \& Swartz, P. (2020). Understanding the economic shock of coronavirus. Harvard Business Review. Retrieved from https:// hbr.org/2020/03/understanding-the-economic-shock-of-coronavirus

Chaturvedi, H., Dey A. K., \& Singh, N. (2020). Coping with COVID-19. Global Focus the EFMD Business Magazine. Retrieved from https:/ www.globalfocusmagazine.com/coping-with-covid-19/

Cundy, A. B., Bardos, R. P., Church, A., Puschenreiter, M., Friesl-Hanl, W., Muller, I., et al. (2013). Developing principles of sustainability and stakeholder engagement for "gentle" remediation approaches: The European context. Journal of Environmental Management, 129, 283-291. doi:10.1016/ j.jenvman.2013.07.032

Dierksmeier, C. (2016). What is "humanistic" about humanistic management? Humanistic Management Journal, 1, 9-32. doi:10.1007/s41463-016-0002-6

Gautrey, C. (2013, June 11). Seven guiding principles of stakeholder engagement. Retrieved from https://www.td.org/insights/seven-guiding-principles-ofstakeholder-engagement

Gjaja, M., Fæste, L., Hansell, G., \& Hohner, D. (2020, April 16). COVID-19: Win the fight, win the future. Boston Consulting Group. Retrieved from https://www.bcg.com/en-hu/publications/2020/covid-scenario-planning-winning-the-future-series

Hamel, G. (2009). Moon shots for management. Harvard Business Review, 87(2), 91-98. Retrieved from https://hbr.org/2009/02/moon-shots-for-management 
Hautz, J., Seidl, D., \& Whittington, R. (2017). Open strategy: Dimensions, dilemmas, dynamics. Long Range Planning, 50(3), 298-309. doi:10.1016/j.lrp.2 016.12.001

Heichler, E. (2020). Seize the moment. MIT Sloan Management Review. Retrieved from https://sloanreview.mit.edu/article/seize-the-moment/?og=Fall $+2020+$ Issue+Horizontal

Horner, C., \& Wilmshurst, T. (2016). Stakeholder engagement and the GRI: Implications for effective risk management. Corporate Ownership \& Control, 13(3), 209-218. doi:10.22495/cocv13i3c1p7

Ignatius, A. (2019). Profit and purpose. Harvard Business Review, 97(2), 10.

King, K., \& Wald, D., \& Manly, J. (2020, April 21). Advantage beyond the crisis. Boston Consulting Group. Retrieved from https://www.bcg.com/en-hu/ publications/2020/building-business-advantage-beyond-covid-19-crisis

Lawrence, A. T. (2017). The drivers of stakeholder engagement: Reflections on the case of Royal Dutch/Shell. In J. Andriof, S. Waddock, B. Husted, \& S. S. Rahman (Eds.), Unfolding stakeholder thinking: Theory, responsibility and engagement (pp. 185-200). New York: Routledge. doi:10.4324/97813512 81881

MacNicol, D., Giffin, G., \& Mansell, P. (2014). Stakeholder engagement: RICS guidance note. London, UK: Royal Institution of Chartered Surveyor. Retrieved from https://www.apm.org.uk/media/6673/stakeholder_engagement_ 1st_edition_pgguidance_2014.pdf

McKee, A. (2017). Happiness traps. How we sabotage ourselves at work. Harvard Business Review, 95(5), 66-73.

Narayandas, D., Hebbar, V., \& Li., L. (2020). Lessons from Chinese companies' response to Covid-19. Harvard Business Review. Retrieved from https:// hbr.org/2020/06/lessons-from-chinese-companies-response-to-covid-19

Nicolescu, O., Popa, I., \& Dumitrascu, D. (2020). Abordari si Studii de Caz Relevante Privind Managementul Organizatiilor din Romania in Contextul Pandemiei Covid-19. București, România: Editura Pro Universitaria.

Nicolescu, O., \& Verboncu, I. (2008). Fundamentele Managementului Organizației. București, România: Editura Universitară.

Peng, T.-J. A., Yen, M.-H., \& Bourne, M. (2017). How rival partners compete based on cooperation? Long Range Planning, 51(2), 351-383. doi:10.1016/ j.lrp.2017.10.003

Pfeffer, J. (2009). Shareholders first? Not so fast... Harvard Business Review, 87(7/8), 90-91. Retrieved from https://hbr.org/2009/07/shareholders-first-notso-fast

Radjou, N. (2020). The rising frugal economy. MIT Sloan Management Review. Retrieved from https://sloanreview.mit.edu/article/the-rising-frugal-economy/

Romeo, J., Moukanas, H., \& Rung, G. (2020). The age of accelerating strategy breakthroughs. MIT Sloan Management Review. Retrieved from https:// sloanreview.mit.edu/article/the-age-of-accelerating-strategy-breakthroughs/

Sadun, R., Bloom, N., \& Van Reenen, J. (2017). Why do we undervalue competent management? Harvard Business Review, 95(5), 120-127.

Sanner, B., \& Bunderson, J. S. (2018). The truth about hierarchy. MIT Sloan Management Review. Retrieved from https://sloanreview.mit.edu/article/thetruth-about-hierarchy/ 


\section{Stakeholders-Based Management System}

Searcy, C. (2018). Defining true sustainability. MIT Sloan Management Review. Retrieved from https:/sloanreview.mit.edu/article/defining-true-sustainability/

Waldron, T., \& Wetherbe, J. (2020). Ensure that your customer relationships outlast coronavirus. Harvard Business Review. Retrieved from https:// hbr.org/2020/04/ensure-that-your-customer-relationships-outlast-coronavirus

Wicks, A. C., \& Harrison, J. S. (2017). Toward a more productive dialogue between stakeholder theory and strategic management. In D. M. Wasieleski \& J. Weber (Eds.), Stakeholder Management - Business and Society 360 (pp. 249-273). Bingley, UK: Emerald Publishing Limited. 10.1108/S2514-175 920170000012

Williamson, P. J., \& De Meyer J. A. (2012). Ecosystem advantage: How to successfully harness the power of partners. California Management Review, 55(1), 24-46. Retrieved from https://ink.library.smu.edu.sg/cgi/viewcontent. cgi? article $=4518 \&$ context=lkcsb_research $10.1525 / \mathrm{cmr} .2012 .55 .1 .24$

Worsley, L. M. (2016). Stakeholder-led project management: Changing the way we manage projects. New York: Business Expert Press.

Zitek, E. M., \& Tiedens, L. Z. (2012). The fluency of social hierarchy: The ease with which hierarchical relationships are seen, remembered, learned, and liked. Journal of Personality and Social Psychology, 102(1), 98-115. doi: $10.1037 / \mathrm{a} 0025345$. 